\title{
CORRIGENDA
}

\section{Lentiviral marking of patient-derived acute lymphoblastic leukaemic cells allows in vivo tracking of disease progression}

S Bomken, L Buechler, K Rehe, F Ponthan, A Elder, H Blair, CM Bacon, J Vormoor and O Heidenreich

Leukemia (2013) 27, 1792; doi:10.1038/leu.2013.113

Correction to: Leukemia (2013) 27, 718-721; doi:10.1038/ leu.2012.206

Since the publication of this article, the authors have noticed an omission in the acknowledgements section, namely that 'Cancer Research UK' was not included.

The corrected acknowledgements appear here.
L4951. SB is funded by a Medical Research Council (MRC) Clinical Research TrainingFellowship. The IVIS Spectrum was funded by a grant from the Wellcome Trust, grant 087961 . Additional funding came from a programme grant by CR-UK (grant number C27943/A12788), project funding from Leukaemia Lymphoma Research (LLR) and core infrastructure support from the North of England Children's Cancer Research Fund (NECCR).

The authors would like to apologize for any inconvenience this may have caused.

\section{ACKNOWLEDGEMENTS}

We thank Christopher Baum and Olga Kustikova for their help with the ligationmediated PCR, and Martin Stanulla and Martin Schrappe for the provision of sample

\section{Clinical value of flow cytometric immunophenotypic analysis for minimal residual disease detection in autologous stem-cell products of follicular and mantle cell lymphomas}

H Kato, K Yamamoto, Y Oki, S Ine, H Taji, D Chihara, Y Kagami, M Seto and Y Morishima

Leukemia (2013) 27, 1792; doi:10.1038/leu.2013.134

Correction to: Leukemia (2012) 26, 166-169; doi:10.1038/ leu.2011.183

Since the publication of this paper, the authors have noticed errors on pages 167 and 168 of their article. The correct sentences are shown below.

'The major translocation cluster on $\mathrm{BCL}-1 / \mathrm{JH}$ consensus primer was used for MCL as reported by Andersen et al. ${ }^{4}$ Also, patientspecific clonally rearranged immunoglobulin heavy chain genes were evaluated using primer sets of Fr2A and LJH/VLJH. ${ }^{10}$ First, we performed semi-nested PCR using lymphoma cell lines with dilution series and found that maximum sensitivity of PCR was $1.0 \times 10^{-5}$. Six patients could not be tested for PCR assessment owing to lack of available primary samples. Four patients were excluded because of negative results of PCR analysis for primary samples. Finally, PCR analysis was performed in a total of 20 patients (Table 2). Fourteen FL patients had the detectable MBR/
$\mathrm{JH}$ rearrangement and five MCL patients could be evaluated using primer sets of immunoglobulin heavy chain rearrangement. Three MCL patients had the $t(11 ; 14)$ breakpoints detected by PCR, two of which could be evaluated with both the $t(11 ; 14)$ breakpoints and immunoglobulin heavy chain rearrangement.'

The Authors would like to apologize for any inconvenience this may have caused.

\section{REFERENCES}

4 Andersen NS, Donovan JW, Borus JS, Poor CM, Neuberg D, Aster JC et al. Failure of immunologic purging in mantle cell lymphoma assessed by polymerase chain reaction detection of minimal. residual disease. Blood 1997; 90: 4212-4221.

10 Ramasamy I, Brisco M, Morley A. Improved PCR method for detecting monoclonal immunoglobulin heavy chain rearrangement in B cell neoplasms. J Clin Pathol 1992; 45: 770-775. 